\title{
A palynological and palaeoclimatological record from the southern Philippines since the Last Glacial Maximum
}

\author{
BIAN YePing $^{1 *}$, JIAN ZhiMin $^{1}$, WENG ChengYu ${ }^{1}$, KUHNT Wolfgang ${ }^{2}$, BOLLIET Timothé ${ }^{2} \&$ \\ HOLBOURN Ann ${ }^{2}$
}

\author{
${ }^{1}$ State Key Laboratory of Marine Geology, Tongji University, Shanghai 200092, China; \\ ${ }^{2}$ Institute of Geosciences, University of Kiel, Kiel 24118, Germany
}

Received December 9, 2010; accepted May 13, 2011

\begin{abstract}
A palynological analysis of a marine sediment core in the southern Philippines, provides a detailed regional vegetation and climate history for the West Pacific Warm Pool (WPWP) since the Last Glacial Maximum (LGM). Chronology was determined by a detailed oxygen isotope record. A higher representation of pollen from tropical upper montane rainforest during the LGM indicate that this forest type moved down along elevation, probabaly due to the lowered temperature. During the last deglaciation and the early Holocene, mangroves were more expanded and tropical mid and upper montane rainforests were restricted, suggesting a rising sea-level and temperature increase. Herbaceous pollen and pteridophyte spore records indicate a much drier condition during the LGM than the Holocene. Mangrove development is controlled by conditions at the river mouth influenced by river discharge. Pteridophyte spores are abundant in wet conditions and are mainly transported by rivers. During the mid-Holocene, the reduction in mangrove pollen and pteridophyte spore appears to be a result of climate change: mainly decrease in river discharge. This may have been affected by the decreasing intensity of the Southeast Asian Monsoon, and the increasing frequency and intensity of warm ENSO events, El Niño, in this region.
\end{abstract}

Last Glacial Maximum, tropical rainforests, palynological analyses, sea-level change, river discharge

Citation: Bian Y P, Jian Z M, Weng C Y, et al. A palynological and palaeoclimatological record from the southern Philippines since the Last Glacial Maximum. Chinese Sci Bull, 2011, 56: 2359-2365, doi: 10.1007/s11434-011-4573-1

Climatic changes in the low latitudes have been a focus for Quaternary paleoclimatic research. Tropical rainforests have the highest biodiversity, and is expected to respond to the climate changes in the glacial-interglacial cycles, either in the components or in the structure of the vegetation. Pollen records in tropical regions of Africa, America and the western Pacific indicate that tropical vegetation has changed obviously during the glacial period, with clear movement of montane trees to lower altitudes at most sites [1]. Both terrestrial and marine records from the tropics show that the tropical montane rainforest expanded during each glacial period. The regional treeline was about $1800 \mathrm{~m}$ lower during the Last Glacial Maximum (LGM) than today, which is much more than the $1100 \mathrm{~m}$ shift in snowline [2,3]. This

\footnotetext{
*Corresponding author (email: ping981201@163.com)
}

means that both temperature and moisture have considerable influence on the distribution of vegetation.

During the last glacial period, the temperature in the West Pacific Warm Pool (WPWP) dropped significantly, as well as the moisture. However changes in precipitation differed somewhat between regions. Most palynological studies have provided clear evidence of cooler and drier glacial conditions at low latitudes, such as in the Indonesian Archipelago, northern Australia, tropical America and Africa [4,5]. Sahul Shelf in northwest Australia, for example, was exposed during the LGM, and was mainly covered by grassland. In pollen assemblages, only a small amount of tropical montane rainforest, tropical lowland rainforest and some fern spores were observed. This indicates a dry and cool condition. In contrast, tropical rainforest was widely distributed over Sumatra and Java during the last glacial 
period [6-8], and the Sunda shelf, in southern South China Sea, was covered by tropical rainforest and mangroves, not grassland $[9,10]$.

However, previous studies of this region have been limited to land. Some research has been done on or near continental shelves, but these records may have been interrupted when the shelves exposed. Thus we hope that a marine core in an area with a high sedimentation rate and is close to the WPWP, could aid the study of vegetation history and its relationship with climate change. The role of the WPWP in the global climate changes could also be inferred.

Greatest mangrove species diversity is found in the tropical western Pacific, from mainland Malaysia through the Indonesian Archipelago to New Guinea and northern Australia. Mangrove distribution is influenced by climate and coastal physiography. The presence of mangrove pollen in sediment records may thus indicate changes of sea level and variations of precipitation affected by the monsoon and by the El Niño-Southern Oscillation (ENSO). Here we report a high resolution palynological analysis of a marine core from the WPWP, and accrordingly a continuous vegetation reconstruction since the last glacial.

\section{Materials and methods}

A Calypso core MD06-3075 was taken within Davao Gulf in the southern Philippines, $6^{\circ} 29^{\prime} \mathrm{N}, 125^{\circ} 50^{\prime} \mathrm{E}$, as a part of a joint French-Chinese marine geological research program (Figure 1). This site is located in the West Pacific where the monthly mean temperature is around $21^{\circ} \mathrm{C}$ all year and annual precipitation is between 8100 and $500 \mathrm{~mm}$, usually more than $2000 \mathrm{~mm}$. Precipitation is greatest in summer, with roughly $80 \%$ of the annual rainfall occurring between June and October. Rainfall averages between 300 and 400 $\mathrm{mm} / \mathrm{month}$ during summer, and between 50 and 100 $\mathrm{mm} / \mathrm{month}$ during winter [11]. The annual precipitation pattern is tied to the migration of the Intertropical Convergence Zone (ITCZ) over the site, the intensity of the East Asian monsoon and the ENSO system $[11,12]$. In these high temperature and rainfall conditions, the vegetation is enormously rich compared with that of temperate lands. The number of species per unit area is very large; these may be up to 200 species of flowering plants per hectare [13]. However, each species is likely to be represented by only a few individuals in each hectare [13].

This 30.76-m-long core was collected in a water depth of $1878 \mathrm{~m}$, and at a distance of $30 \mathrm{~km}$ from land. The results of pollen analyses for the upper $16 \mathrm{~m}$ of this core is reported in this paper. Samples were extracted at $20 \mathrm{~cm}$ intervals resulting in a total of 80 samples for palynological analysis. For every sample, $10 \mathrm{~cm}^{3}$ of sediment was processed using the following procedures: The sediment was sieved through a $7 \mu \mathrm{m}$ mesh after hydrochloric acid $(10 \%)$ treatment, and hydrofluoric acid $(55 \%)$ treatment to remove carbonates and
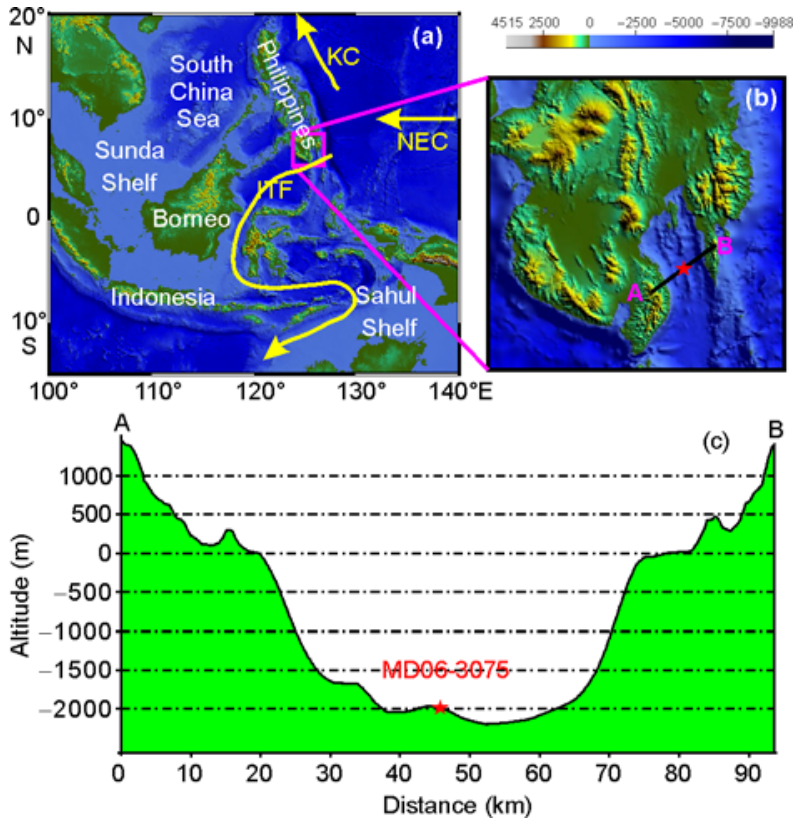

Figure 1 (a) General location of the study area and ocean currents, including the Kuroshio Current (KC), North Equator Current (NEC), and Indonesian Throughflow (ITF); (b) Location of the studied core MD063075 in the southern Philippines; (c) Topography near the core (red star).

silicates. Slides were mounted in glycerol and sealed with paraffin wax. All predominantly terrestrial taxa (rainforest taxa, mangroves and herbs) were included in the total pollen count on which percentages of all taxa are based. Palynomorph concentration was established by adding a known quantity of Lycopodium marker spores to each sample prior to treatment, and was expressed as numbers of grains per $\mathrm{cm}^{3}$.

\section{Results}

\subsection{Chronology}

Marine oxygen isotope data of core MD06-3075 were provided by T. Bolliet (personal communication, unpublished). We compared detailed Planktonic Foraminifera $\delta^{18} \mathrm{O}$ records between core MD06-3075 and MD98-2181 $\left(6.3^{\circ} \mathrm{N}\right.$, $125.83^{\circ} \mathrm{E}$, controlled with reliable AMS ${ }^{14} \mathrm{C}$ dates $\left.[11,14]\right)$, gaining five control points: these were the transition between Marine Oxygen Isotopic Stage (MIS) 3 and 2, the LGM period, the Younger Dryas event and several points in the Holocene (Figure 2). Ages were linearly interpolated between control points. Our age model indicates that the upper $16 \mathrm{~m}$ of core MD06-3075 covers the last $30 \mathrm{ka}$.

\subsection{Palynological results}

The pollen types identified can be grouped as follows, according to their ecology. (1) Tropical mid-upper montane rainforest group: Phyllacladus, Podocarpus, Dacrydium, 


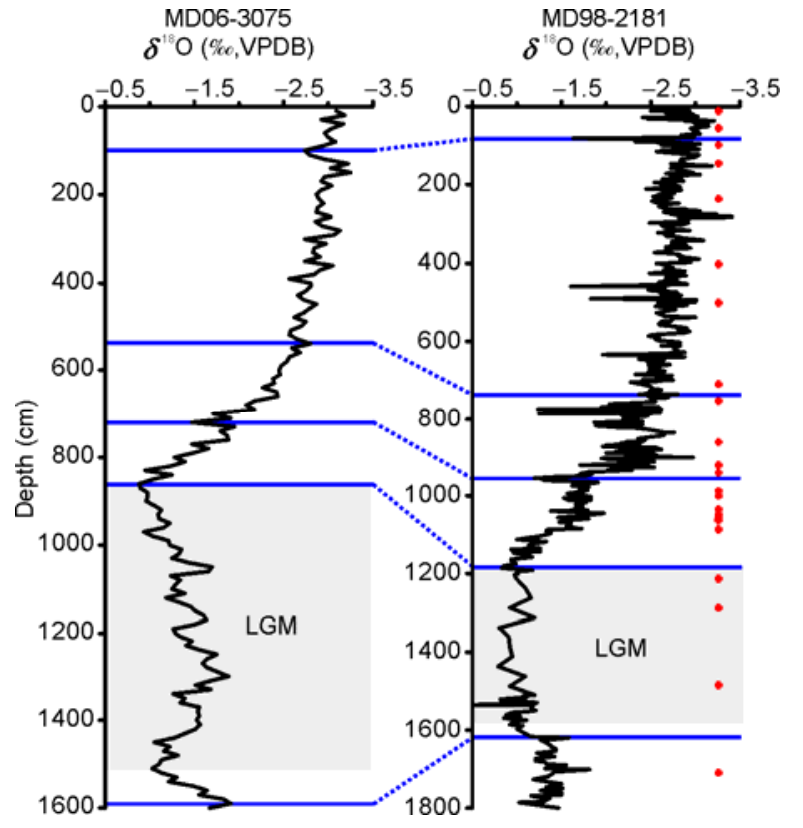

Figure 2 Comparison of the oxygen isotope record of core MD06-3075 and MD98-2181. Red crosses indicate $\mathrm{AMS}^{14} \mathrm{C}$ ages in the MD98-2181 core $[11,14]$; blue lines indicate control points used; shading approximates the LGM.

Myrica and Rhododendron; (2) tropical lower montane rainforest group: Quercus, Castanopis, Myrtaceae and Elaeocarpaceae; (3) tropical lowland rainforest group: Sapindaceae, Moraceae, Meliaceae, Rubiaceae Rutaceae, and so on (usually including a large number of taxa, but with only a few pollen grains for each taxon); (4) mangrove: Rhizophora, Bruguiera, Sonneratia; and (5) herbs: mainly Poaceae and Cyperaceae.

Our pollen diagram is divided into four zones based on changes in percentages and concentrations of pollen for individual taxa or ecological groups (Figures 3 and 4):

Zone P1 (16-12.9 m; 30000-23000 cal a BP) is characterized by very high values of pollen from tropical upper montane rainforest and tropical lowland rainforest taxa. Pollen from tropical lower montane rainforest, herb and mangrove taxa is less important. There is a noticeable peak in the tropical upper montane rainforest taxa, especially Phyllacladus and Podocarpus; the pollen percentage from this ecological group averages $30 \%-40 \%$, and up to $45 \%$. Pollen record from tropical lower montane rainforest and lowland rainforest taxa shows little change compared with tropical upper montane rainforest. Pollen numbers from mangrove and herbaceous taxa are much low, mostly less than $5 \%$. The percentage of pteridophyte spores is about $200 \%$, and shows a slight decline in this zone. The concentration diagram shows the same pattern of changes represented by percentage curves.

Zone P2 (12.9-7.4 m; 23000-13000 cal a BP) corresponds to late MIS 2. In this zone, the pollen assemblage shows little difference from the previous zone. However, a number of tropical upper montane rainforest and herbaceous taxa do show some variation in representation. The most noticeable feature of this zone is the striking increase of pollen from herbaceous taxa, especially Poaceae, and a slight reduction in tropical upper montane rainforest taxa, mainly Phyllacladus and Podocarpus. Pteridophyte spores drop to the lowest level of the whole record in this study. The concentration curves show obvious variation in individual taxa and ecological groups. Except for a number of tropical lower montane rainforest taxa and mangroves, the amplitude of change in concentration is larger than that in the presentage record. The pollen concentration for tropical upper montane and lowland rainforest fluctuates greatly in this zone, while that of herbaceous taxa and total pollen maintain at high levels. Pteridophyte spores increase significantly during the later part of this zone.

Zone P3 (7.4-2.8 m; 12000-5000 cal a BP) is distinguished by the dominace of pollen from mangrove taxa. Regular changes are observed in the representation of tropical lowland, upper and lower montane, herbaceous taxa and pteridophytes. The percentage of mangrove pollen increases rapidly from $5 \%$ to $38 \%$, then fluctuates at around $35 \%$; this is mainly the result of a resurgence of Rhizophora taxa, and some Bruguiera taxa. Pollen from tropical upper montane rainforest taxa is much less abundant, declining by $20 \%$ from the previous zone, and is mainly Podocarpus. Pollen from herbaceous taxa is generally less, as the major component, Poaceae, declines to close to zero in the later part of this zone. The value of pteridophyte is much higher than in the previous zone, increasing from $200 \%$ to $400 \%$. There is a marked reduction in the concentration of all elements, approximately half of that in zone $\mathrm{P} 2$.

Zone P4 (2.8-0 m; 5000-0 cal a BP) shows relatively high abundance of pollen from tropical lowland rainforest and mangrove taxa, but much less abundance of herbaceous, tropical upper and lower montane rainforest pollen. The most noticeable feature of this zone is the striking decline in mangrove pollen, fluctuating at only about $10 \%$, and both Rhizophora and Bruguiera are less abundant. In general, tropical upper montane rainforest pollen and pteridophyte spores are slightly less abundant than in the previous zone. Poaceae and Cyperaceae pollen increases in the later part of this zone.

\section{Discussion}

\subsection{Vegetation history}

The pollen assemblages from the MD06-3075 core demonstrate that there have been substantial changes in tropical upper montane rainforest. It is inferred from our vegetation reconstruction that temperature shows an increase trend since the last glacial period. Tropical montane forest occurs at high altitudes today, far away from the study site. Pollen percentage for this group is influenced by vegetation cover, and distance between the sedimentation point and the vegetation 

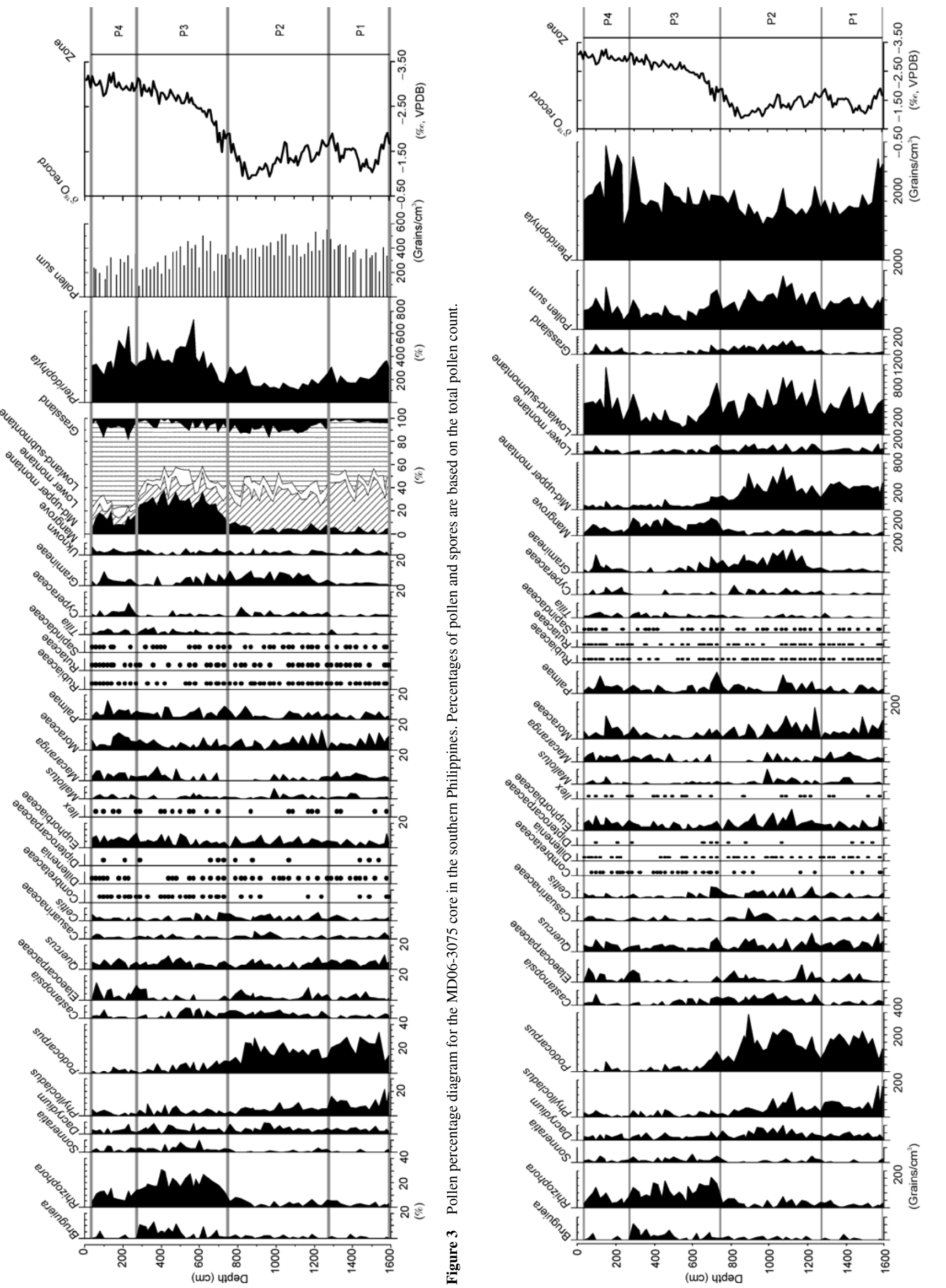
source. When the climate cooled, montane trees migrated to lower altitudes, adapting to an environment more similar to their original ecology. Lower altitudes are usually larger in area than that of higher altitudes, providing more space for the upper montane forest to expand, and the distance to the sediment deposition site is shorter. This leads to an increase in representation of montane taxa in marine cores. Conversely, when the climate warmed, montane trees distributed to high altitudes, and the pollen percentages found at low altitude are low. Although other ecological groups show a similar pattern of change, taxa living at high altitudes, including the upper and lower montane trees, are more sensitive to temperature changes. Thus the pollen spectrum shows more noticeable changes for this group.

At the beginning of the record (in zone P1), the vegetation cover was dominated by tropical upper montane and lowland rainforests, but the tropical lower montane rainforest, open herbaceous swamp vegetation and mangrove were suppressed. The pollen assemblages recorded in the early part of zone P2 show that the percentage of tropical upper montane rainforest declined, but the pollen concentration from this source increased, while the percentage and concentration of herbaceous taxa both increased significantly, and eventually reaching its highest levels of this study. All of these suggest an expansion of tropical upper montane rainforest to the low altitudes, and a great development of the herbaceous cover, reflecting the cooler and drier climate conditions during the LGM.

The reduction in montane and the herbaceous taxa, as determined from the pollen signal recorded in the later part of zone P2 and early part of zone P3, indicates the onset of warmer and wetter climatic conditions during the last deglaciation and early Holocene. Meanwhile, the content of pteridophyte spores increased, presenting that this vegetation type was well-developed, possibly indicating enhanced fluvial transport caused by the high precipitation. The relatively high levels of herbaceous pollen during the late Holocene suggest a more open environment than in the early Holocene; but the whole area was mostly covered by the tropical lowland rainforest.

Thus, based on the changes in vegetation distribution in the southern Philippines, a cooler and drier climate during the LGM than in the other preiods represented by the other pollen zones is recorded. This is also supported by other palynological analyses in the West Pacific region. Terrestrial records from high altitudes in Java and Sumatra also show that the high elevation vegetation belts in these regions moved down to lower altitudes during the glacial period [8]. Marine records from the southern and northern South China Sea and from northern Australia, show that pollen abundance from tropical montane rainforest taxa was high at the LGM [15-18]. We found that total pollen concentration was high; probably as a result of vegetation cover on the exposed shelf during lower sea level leading to the vegetation source close to the MD06-3075 core. Some sup- port for this hypothesis is provided by the generally much higher total pollen influx in marine cores in the southern South China Sea during the glacial period, when the continental shelves were exposed, than during the interglacial [16]. In addition, the percentage of mangrove taxa was much lower during the glacial; this may indicate that the numbers of mangrove taxa were suppressed, perhaps because the coastline located in steep areas caused as a result of the lower sea level (Figure 1(c)).

\subsection{Mangrove pollen record and seal-level change}

Mangroves are almost always found in estuaries, lagoons, or less commonly, in the shelter of coral reefs or islands; in other words on low wave-energy coasts. Most of these are muddy rather than sandy or rocky. Climatic factors that affect the distribution of mangroves include changes in sea level, precipitation, and temperature [16,19]. Given that mangroves generally grow between mean sea-level and mean high water, their sedimentary records have been used as both directional and precise sea-level indicators [19-22].

In general, changes shown by mangroves correspond to the sea level change in our study. During the LGM, both the percentage and concentration of mangrove pollen were low. The coast was probably steeply sloping when the sea level was low (about $120 \mathrm{~m}$ lower than the present day at LGM), resulting in restriction of mangrove habitat due to a lack of suitable river estuaries on the newly exposed continental shelf (Figures 3, 5(b), (c)) [23,24]. As sea level rose dramatically during the deglacial, the mangrove vegetation displayed a prosperous picture because of increasing suitable coastline space for mangrove development. This change pattern of mangrove pollen is also identified from the marine core in the West Pacific [20,21]. In addition, the total pollen concentration was lowering at the same time, as the distance between our marine core and the vegetation source increased due to sea level rise.

The marine core pollen records indicate subdued mangrove development during the mid Holocene. The pollen records from southern Kalimantan and Sulawesi in the Makassar strait also show high abundance of mangrove pollen during the early Holocene on both sides of the Strait, and a decline during the mid Holocene [25]. The relative sea level record shows that it is about 2 or 3 meters higher during the early Holocene than it is today (Figure 5(c)) [23,24]. Given the variation in amplitude of sea level change in the deglacial or mid-Holocene periods, the poorly developed mangroves during the late Holocene were not only influenced by sea level falling, but also by other environmental or climatic condition changes.

\subsection{Palaeoclimatic reconstructions and possible mechanism}

Our tropical vegetation pollen record shows that the climate 
during the Holocene was not stable. During the early Holocene, mangroves were much more prosperous than in the late Holocene. Given the special ecology of mangroves, and their need for tropical, low wave-energy coasts, mangrove development was influenced by available coastline space resultant from sea level change, and also other environmental and climatic factors. Mangroves are widespread, and species richness is highest in humid areas, where mangrove habitats include a number of species with modest salinity tolerance [21]. Thus the link between humid climate and optimal mangrove development in modern settings is a strong one [21]. In addition, estuarine environments are influenced by river discharge. When runoff is high, this benefits the expansion of deltas, and the space for mangrove development increase. Our sediment core, therefore, records higher spore or pollen abundance of taxa from wetter environments: pteridophytes, mangroves and lowland rainforest taxa, but lower abundance of herbaceous pollen, during the early Holocene. This demonstrates that there was much greater moisture in this region during the early Holocene.

The region includes high mountains on islands along the west Pacific, and short rivers flow rapidly from these mountains. River discharge is to some extent controlled by the precipitation [17,26-28]. Meanwhile, previous studies suggest that this region's humidity has a great relationship with the monsoon and the ENSO system [26-33]. As strong summer insolation in the northern hemisphere during the early Holocene induced strong land-ocean pressure and temperature gradients and increased onshore moist air flow during the summer, this enhanced the Asian summer monsoon [30-33]. The stalagmite $\delta^{18} \mathrm{O}$ value in Dongge cave, China, reflects a gradual weakening in the East Asian summer monsoon since $8 \mathrm{ka}$ (Figure 5(d),(e)) [32-34]. Although the stalagmite record in northern Borneo is closer to our site than that in China, further research has indicated that the stalagmite $\delta^{18} \mathrm{O}$ value in northern Borneo is influenced by insolation from both northern and southern hemispheres [34]. The Holocene discharge trends in tropical monsoon river basins influenced by North Hemisphere summer monsoons closely follow the orbitally forced decrease in precipitation [29]. For example, the mean discharges of the Asian Mekong and Ganges rivers decreased by $28 \%$ and $30 \%$, respectively [29]. The western tropical Pacific experiences dramatic differences in precipitation during the modern $\mathrm{El}$ Niño and La Niña. Summer precipitation over northern Indonesia, for example, can be diminished by as much as $60 \%$ during a major El Niño [12]. A record of sedimentation in Laguma Pallcacocha, southern Ecuador, which is strongly influenced by ENSO variability, suggests that a strong increase in ENSO warm events and frequency took place during the late Holocene [35]. Therefore, the climate inferred from fossil pollen records in our study generally correlates with the East Asian summer monsoon and ENSO intensity records as discussed above: a moist phase during the early Holocene followed by a gradual decrease in

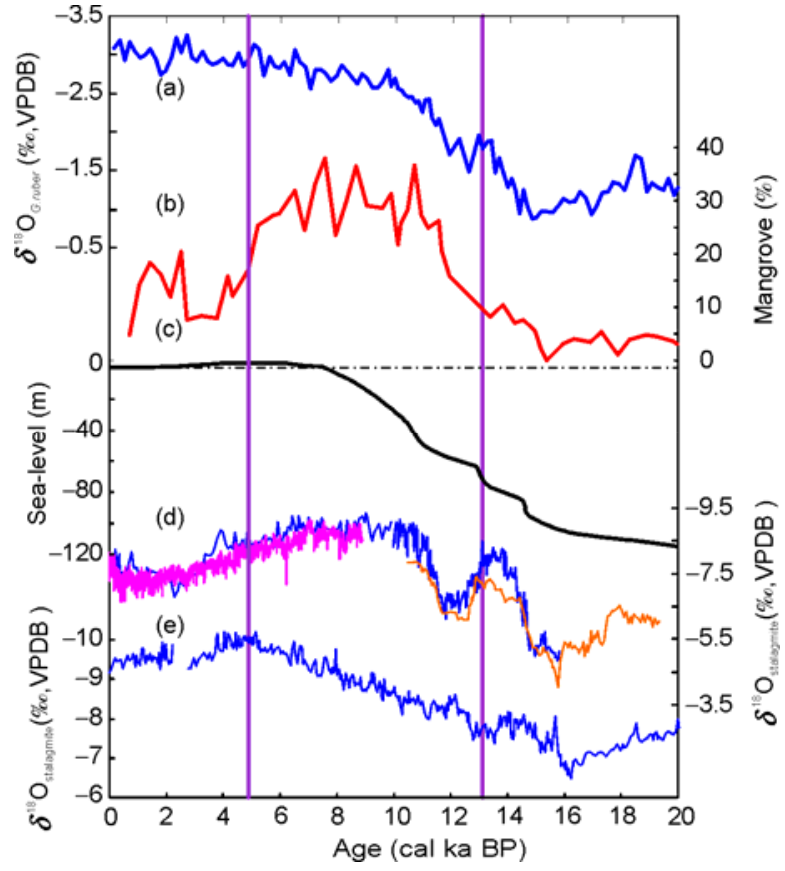

Figure 5 Comparison of the MD06-3075 pollen record with other palaeoclimate records. (a) The planktonic foraminifera $\delta^{18} \mathrm{O}$ record of core MD06-3075; (b) the percentage of mangroves in core MD06-3075; (c) relative sea level change in the South China Sea (adapted from [24]); (d) stalagmite $\delta^{18} \mathrm{O}$ record for Dongge cave, China [32,33]; (e) stalagmite $\delta^{18} \mathrm{O}$ record for Gunung Buda, Borneo [34].

effective moisture during mid-late Holocene.

\section{Conclusion}

Major changes in vegetation and climate conditions since last glacial maximum have been identified by our study of core MD06-3075 from the Davao Gulf in the southern Philippines. During the LGM, an expansion of tropical montane rainforest indicated that temperature was lower than present day, and the high values of total pollen count and low percentage of mangrove pollen reflect a low sea level. During the last deglacial and the Holocene, tropical upper montane rainforest was limited to high altitudes, presenting a great increase in temperature. And the mangroves developed as sea level rose at the same time. During the early Holocene, the large quantities of pollen from wet environment taxa, pteridophytes, mangroves and lowland rainforest taxa, demonstrate a much warmer and wetter climate during this time in the west Pacific.

During the mid-late Holocene, the vegetation groups of mangroves and pteridophytes were suppressed, probably indicating a decline in river discharge, and to a certain extent reflecting weakened East Asian summer monsoon and intensified ENSO variability in the equatorial West Pacific.

Although we would argue that environmental and climate change were responsible for vegetation changes, human behavior will also have contributed to the vegetation shifts 
during the late Holocene.

This work was supported by the National Natural Science Foundation of China (40621063 and 40771072) and the National Basic Research Program of China (2007CB815900).

1 Bush M B, Flenley J R. Tropical Rainforest Responses to Climatic Change. Chichester: Praxis Publishing Ltd, 2007

2 Hope G. Environmental change in the Late Pleistocene and later Holocene at Wanda site, Soroako, South Sulawesi, Indonesia. Palaeogeogr Palaeoclimatol Palaeoecol, 2001, 171: 129-145

3 Peterson J A, Hope G S, Prentice M, et al. Mountain environments in New Guinea and the late Glacial Maximum warm seas/cold mountains enigma in the West Pacific Warm Pool region. In: Kershaw A P, Tapper N J, David B, et al., eds. Bridging Wallace's Line. Adv GeoEcol, Catena Verlag, Reiskirchen, 2002, 34: 173-187

4 Penny D. A 40000 year palynological record from north-east Thailand; implications for biogeography and palaeo-environmental reconstruction. Palaeogeogr Palaeoclimatol Palaeoecol, 2001, 171: 97-128

5 Anhuf D, Ledru M P, Behling $\mathrm{H}$, et al. Paleo-environmental change in Amazonian and African rainforest during the LGM. Palaeogeogr Palaeoclimatol Palaeoecol, 2006, 239: 510-527

6 Maxwell A L, Liu K-B. Late Quaternary pollen and associated records from the monsoonal areas of continental South and SE Asia. In: Kershaw A P, Tapper N J, David B, et al., eds. Bridging Wallace's Line. Adv GeoEcol, Catena Verlag, Reiskirchen, 2002, 34: 189-228

7 Newsome J C, Flenley J R. Late Quaternary vegetational history of the Central Highlands of Sumatra. II. Palaeopalynology and vegetational history. J Biogeogr, 1988, 15: 555-578

8 van der Kaars S, Penny D, Tibby J, et al. Late Quaternary palaeoecology, palynology and palaeolimnology of a tropical lowland swamp: Rawa Danau, West Java, Indonesia. Palaeogeogr Palaeoclimatol Palaeoecol, 2001, 171: 185-212

9 Li X, Sun X. Palynological records since Last Glacial Maximum from a deep sea core in southern South China Sea (in Chinese). Quat Sci, 1999, 6: 526-535

10 Wang X M, Sun X J, Wang P X, et al. A high-resolution history of vegetation and climate history on Sunda Shelf since the last glacial. Sci China Ser D-Earth Sci, 2007, 50: 75-80

11 Scott L, Poulsen C, Lund S, et al. Super ENSO and global climate oscillations at millennial time scales. Science, 2002, 297: 222-226

12 Dai A, Wigley T. Global patterns of ENSO-induced precipitation. Geophys Res Lett, 2000, 27: 1283-1286

13 Whitmore T C. Tropical Rain Forests of the Far East. Oxford: Clarendon Press, 1975. 121-163

14 Stott L. Comment on "Anomalous radiocarbon ages for foraminifera shells". Paleoceanography, 2007, 22: PAPA1211, doi: 10.1029/2006PA 001379

15 Sun X, Li X. A pollen record of the last $37 \mathrm{ka}$ in deep sea core 17940 from the northern slope of the South China Sea. Mar Geol, 1999, 156: $227-244$

16 Sun X, Li X, Luo Y, et al. The vegetation and climate at the last glaciation on the emerged continental shelf of the South China Sea. Palaeogeogr Palaeoclimatol Palaeoecol, 2000, 160: 301-316

17 Kershaw A P, van der Kaars S, Flenley J R. The Quaternary history of far eastern rainforests. In: Bush M B, Flenley J R, eds. Tropical Rainforest Responses to Climatic Change. Chichester: Praxis Publishing Ltd, 2007. 77-115

18 Hope G, Kershaw A P, van der Kaars S, et al. History of vegetation and habitat change in the Austral-Asian region. Quat Int, 2004, 118119: $103-126$

19 Ellison J C. Long-term retrospection on mangrove development using sediment cores and pollen analysis: A review. Aquat Bot, 2008, 89: 93-104

20 Ellison J C. Holocene palynology and sea-level change in two estuaries in Southern Irian Jaya. Palaeogeogr Palaeoclimatol Palaeoecol, 2005, 220: 291-309

21 Grindrod J, Moss P, van der Kaars S. Late Quaternary mangrove pollen records from the continental shelf and ocean cores in the north Australian-Indonesian region. In: Kershaw A P, Tapper N J, David B, et al., eds. Bridging Wallace's Line. Adv GeoEcol, Catena Verlag, Reiskirchen, 2002, 34: 119-146

22 van der Kaars S, Wang X, Kershaw A P, et al. Late Quaternary palaeoecological record from the Banda Sea, Indonesia: Patterns of vegetation, climate and biomass burning in Indonesia and northern Australia. Palaeogeogr Palaeoclimatol Palaeoecol, 2000, 155: 135-153

23 Tanabe S, Hori K, Saito Y, et al. Song Hong (Red River) delta evolution related to millennium-scale Holocene sea-level changes. Quat Sci Rev, 2003, 22: 2345-2361

24 Tanabe S, Saito Y, Vu Q L, et al. Holocene evolution of the Song Hong (Red River) delta system, northern Vietnam. Sediment Geol, 2006, 187: 29-61

25 Yulianto E, Sukapti W S, Rahardjo A T, et al. Mangrove shoreline responses to Holocene environmental change, Makassar Strait, Indonesia. Rev Palaeobot Palynol, 2004, 131: 251-268

26 Flenley J R. Problems of the Quaternary on mountains of the SundaSahul Region. Quat Sci Rev, 1996, 15: 549-555

27 Milly P C D, Dunne K A, Vecchia A. Global pattern of trends in streamflow and water availability in a changing climate. Nature, 2005, 438: $347-350$

28 Lough J M. Tropical river flow and rainfall reconstructions from coral luminescence: Great Barrier Reef, Australia. Paleoceanography, 2007, 22: PA2218, doi: 10.1029/2006PA001377

29 Aerts J C J H, Renssen H, Ward P J, et al. Sensitivity of global river discharges under Holocene and future climate conditions. Geophys Res Lett, 2006, 33: L19401, doi:10.1029/2006GL027493

30 van Campo E. Monsoon fluctuations in two 20000-yr. Oxygenisotope/ pollen records off southwest India. Quat Res, 1986, 26: 376-388

31 Wang P X. Global monsoon in a geological perspective. Chinese Sci Bull, 2009, 54: 1113-1136

32 Wang Y, Cheng H, Edwards R L, et al. A High-resolution absolute-dated Late Pleistocene monsoon record from Hulu Cave, China. Science, 2001, 294: 2345-2348

33 Wang Y, Cheng H, Edwards R L, et al. The Holocene Asian monsoon: Links to solar changes and North Atlantic climate. Science, 2005, 308: 854-857

34 Griffiths M L, Drysdale R N, Gagan M K, et al. Increasing AustralianIndonesian monsoon rainfall linked to early Holocene sea-level rise. Nature, 2009, 605: 637-639

35 Moy C S, Seltzer G O, Rodbell D T, et al. Variability of El Niño/ Southern Oscillation activity at millennial timescales during the Holocene epoch. Nature, 2002, 420: 162-165

Open Access This article is distributed under the terms of the Creative Commons Attribution License which permits any use, distribution, and reproduction in any medium, provided the original author(s) and source are credited. 